\title{
FEATURES OF VEGETATION, FLOWERING AND FRUITING OF THE GENUS SPIRAEA L. SPECIES IN THE CULTIVATION IN THE EUROPEAN NORTH-EAST (REPUBLIC OF KOMI)
}

(C) 2018

Smirnova Anna Nikolaevna, postgraduate student, leading engineer of Botanical Garden

Zaynullina Klavdiya Stepanovna, candidate of biological sciences, senior researcher of Botanical Garden Institute of Biology of Komi Scientific Centre of the Ural Branch of the Russian Academy of Sciences

(Syktyvkar, Russian Federation)

Abstract. The paper deals with the flowering and fruiting of introduced species of Spiraea L. genus in the collection of the Botanical garden of the Institute of biology of Komi SC of Ural branch of RAS, located in the middle taiga subzone of the European North-East of Russia. The collection of Spiraea genus by this time includes more than 40 taxa of plants of different geographical origin, including one species of local flora. Characteristics of vegetation, flowering and fruiting indicators of nine species of perennial plants of the genus are given based on the results of phenological observations during five years. It is shown that the seasonal rhythm of plant development in the new conditions corresponds to the climatic conditions of the subzone of the middle taiga. There are differences in the dates of beginning and duration of flowering in different species Spiraea of three sections, the total duration of flowering of studied species is almost 100 days. The species of Spiraria section are characterized by latest start and a long flowering period. Plants of all studied species are characterized by annual flowering and fruiting with the formation of benign seeds; some species are capable of self-seeding. The revealed characteristics allow us to consider that the studied species of Spiraea genus have successfully adapted in the Northern region and can be used in ornamental horticulture.

Keywords: genus of Spiraea L.; species; ornamental shrubs; introduction; phenological observations; seasonal rhythm of development; vegetation period; generative development; flowering duration; fruiting; seed maturation; botanical garden; middle taiga subzone; European North-East.

УДК 58.009

Статья поступила в редакцию 20.04.2018

\section{СОСТАВ ГИДРОМАКРОФИТОВ ВОДОЕМОВ СЕВЕРО-ВОСТОЧНОЙ ЧАСТИ КУРГАНСКОЙ ОБЛАСТИ}

(C) 2018

Токарь Ольга Егоровна, кандидат биологических наук,

доцент кафедры биологии, географии и методики их преподавания

Ииимский педагогический институт имени П.П. Ершова (филиал)

Тюменского государственного университета (г. Ииим, Тюменская область, Российская Федерация)

Аннотация. В 2017 г. выполнены экспедиционные исследования гидромакрофитной флоры 22 водных объектов Курганской области. Изучение водной флоры проводилось в пределах 6 административных районов Курганской области: Частоозерского (4), Петуховского (2), Макушинского (7), Лебяжьевского (4), Вар-

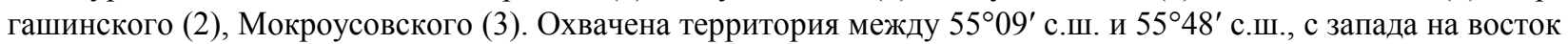
- между $65^{\circ} 53^{\prime}$ в.д. и 6919' в.д. В ходе работы отобраны и зафиксированы образцы макроводорослей, собран гербарий высших гидромакрофитов. Приведены данные о видовом составе, частоте встречаемости гидромакрофитов; выявлено новое местонахождение редкого вида в Курганской области - Ruppia maritima L. Впервые для территории исследования приведен видовой состав макроскопических водорослей. Отмечено, что вид Chara contraria A. Br., является редким, находящимся на северной границе своего распространения, поэтому нуждается в охране. Большинство выявленных видов гидромакрофитов являются распространенными на территории Западно-Сибирской равнины (Северный Казахстан, Тюменская область). Представлена информация о местонахождении инвазионного вида Elodea canadensis Michx. Полученные материалы могут служить основой для дальнейшего проведения гидроботанического обследования водоемов Курганской области.

Ключевые слова: гидромакрофиты; видовой состав; частота встречаемости; водные объекты; Курганская область; Частоозерский район; Петуховский район; Макушинский район; Лебяжьевский район; Варгашинский район; Мокроусовский район; Западно-Сибирская равнина; макроводоросли; редкие виды; Ruppia maritima; Chara contraria; Elodea canadensis.

\section{Введение}

Флора Курганской области считается сравнительно хорошо изученной, особенности ее состава и сложения отражены в монографии Н.И. Науменко [1]. Вышли два издания Красные книги Курганской области [2-3]. Однако работы, посвященные изучению состава и структуры водной флоры разнотипных водоемов Курганской области, отсутствуют. В справочнике [4, с. 10] написано: «флору водоемов Зауралья слагают не менее 118 прибрежно-болотных и 55 водных видов: земноводных, полностью погруженных, плавающих на поверхности или имеющих плавающие листья». Единичны работы, где отражены результаты альгологических исследований [5, с. 866].

Цель проведенного нами исследования состояла в изучении состава водной флоры разнотипных водое- 
мов северо-восточной части Курганской области, выявлении редких видов.

В соответствии с физико-географическим районированием Курганской области территория исследования расположена в пределах южно-лесостепной подобласти Тобол-Ишимской подпровинции $[6$, c. 23].

Географическое положение Курганской области определяет ее климат как континентальный умеренного пояса. Для области характерен циклональноантициклональный тип циркуляции атмосферы с господством западного переноса воздушных масс, который ослаблен зимой усилением сезонного Азиатского антициклона, а летом усилением арктического и субтропического антициклонов, вызывающих меридиональный перенос воздушных масс [7; 4, с. 5-6].

Согласно ботанико-географическому районированию Курганской области, предложенному Н.И. Науменко [8, с. 81, 84-87], территория исследования расположена в пределах Медвежье-Одиновского района Яланско-Курганско-Ишимского лесостепного флористического округа.

Междуречное пространство Тобол-Ишим сравнительно слабо расчленено долинами коротких и маловодных притоков Тобола. На юге отчетливо прослеживаются погребенные древние долины рек в виде широких и плоских лощин, вытянутых с севера на юг. По тальвегу этих рек расположена цепочка озер. Часть озер залегает в хорошо выраженных понижениях - озерных ваннах. Такие озера с восточной стороны окаймлены участками гривно-лощинного рельефа. Значительная часть озер имеет солоноватую горько-соленую воду [4, с. 6-7]. Форма большинства озер круглая или овальная. Берега низкие и плоские. Озерные котловины блюдцеобразные. Все озера очень мелководные, максимальные глубины не превышают 3-4 м, средние - 1-2 м [9; 4, с. 6-7].

\section{объекты исследования}

В полевой период 2017 г. выполнены рекогносцировочные исследования гидромакрофитной флоры 22 водных объектов северо-восточной части Курганской области в пределах 6 административных районов: Частоозерском (4), Петуховском (2), Макушинском (7), Лебяжьевском (4), Варгашинском (2), Мокроусовском (3). Охвачена территория между $55^{\circ} 09^{\prime}$ с.ш. и $55^{\circ} 48^{\prime}$ с.ш., с запада на восток - между $65^{\circ} 53^{\prime}$ в.д. и $69^{\circ} 19^{\prime}$ в.д. Общая протяженность маршрутов составила свыше 1400 км.

Исследуемые водоемы (3 - правые притоки р. Тобол I и II порядка и 19 озер) находятся в пределах Тобол-Ишимского междуречья.

Ниже перечислены исследованные водные объекты с указанием географических координат точек сбора полевого материала (табл. 1).

Для исследуемых рек и большинства описанных озер (59\%) характерен грунт - тонкодетритный ил на песке и песчаный (32\%), единично отмечен - песок илистый $(4,5 \%)$, черный тонкодетритный ил на песке $(4,5 \%)$. В 5 озерах (23\%) на момент исследования было отмечено цветение воды, вызванное массовым размножением цианобактерий. Особенно это явление было выражено в оз. Северное.
Таблица 1 - Исследованные водоемы северовосточной части Курганской области (2017г.)

\begin{tabular}{|c|c|c|}
\hline \begin{tabular}{c|} 
№ \\
$\Pi / \Pi$
\end{tabular} & Название водоема & $\begin{array}{c}\text { Географические } \\
\text { координаты }\end{array}$ \\
\hline \multicolumn{3}{|c|}{ Частоозерский р-н } \\
\hline 1 & Оз. Песьяное & $55^{\circ} 40^{\prime}$ с.ш., $68^{\circ} 08^{\prime}$ в.Д. \\
\hline 2 & Оз. без названия & $55^{\circ} 35^{\prime}$ с.ш., $67^{\circ} 57^{\prime}$ в.д. \\
\hline 3 & Оз. Мартыново & $55^{\circ} 34^{\prime}$ с.ш., $67^{\circ} 53^{\prime}$ в.Д. \\
\hline 4 & Оз. Северное & $55^{\circ} 23^{\prime}$ с.Ш., $67^{\circ} 50^{\prime}$ в.Д. \\
\hline \multicolumn{3}{|c|}{ Петуховский р-н } \\
\hline 5 & Оз. без названия & $55^{\circ} 15^{\prime}$ с.Ш., $68^{\circ} 00^{\prime}$ в.Д. \\
\hline 6 & Оз. Варакосово & $55^{\circ} 09^{\prime}$ с.ш., $67^{\circ} 46^{\prime}$ в.Д. \\
\hline \multicolumn{3}{|c|}{ Макушинский р-н } \\
\hline 7 & Оз. Аистово & $55^{\circ} 18^{\prime}$ с.ш., $67^{\circ} 21^{\prime}$ в.д. \\
\hline 8 & Оз. без названия & $55^{\circ} 18^{\prime}$ с.ш., $67^{\circ} 23^{\prime}$ в.д. \\
\hline 9 & Оз. без названия & $55^{\circ} 20^{\prime}$ с.ш., $67^{\circ} 23^{\prime}$ в.д. \\
\hline 10 & Оз. Исаково & $55^{\circ} 20^{\prime}$ с.ш., $67^{\circ} 24^{\prime}$ в.д. \\
\hline 11 & Оз. Малое Коровье & $55^{\circ} 16^{\prime}$ с.ш., $67^{\circ} 07^{\prime}$ в.д. \\
\hline 12 & Оз. без названия & $55^{\circ} 22^{\prime}$ с.ш., $67^{\circ} 03^{\prime}$ в.д. \\
\hline 13 & Оз. Старково & $55^{\circ} 23^{\prime}$ с.ш., $67^{\circ} 03^{\prime}$ в.д. \\
\hline \multicolumn{3}{|c|}{ Лебяжьевский р-н } \\
\hline 14 & Оз. Светлое & $55^{\circ} 24^{\prime}$ с.ш., $66^{\circ} 46^{\prime}$ в.д. \\
\hline 15 & Оз. Снегирево & $55^{\circ} 26^{\prime}$ с.ш., $66^{\circ} 44^{\prime}$ в.д. \\
\hline 16 & Оз. Суерское & $55^{\circ} 26^{\prime}$ с.ш., $66^{\circ} 36^{\prime}$ в.Д. \\
\hline 17 & Оз. Соленое & $55^{\circ} 24^{\prime}$ с.ш., $66^{\circ} 16^{\prime}$ в.д. \\
\hline \multicolumn{3}{|c|}{ Варгашинский р-н } \\
\hline 18 & Оз. Максимково & $55^{\circ} 26^{\prime}$ с.ш., $65^{\circ} 53^{\prime}$ в.д. \\
\hline 19 & Оз. Лихачевское & $55^{\circ} 30^{\prime}$ с.Ш., $65^{\circ} 59^{\prime}$ в.Д. \\
\hline \multicolumn{3}{|c|}{ Мокроусовский р-н } \\
\hline 20 & Р. Марай & $55^{\circ} 45^{\prime}$ с.Ш., $66^{\circ} 19^{\prime}$ в.Д. \\
\hline 21 & Р. Суерь & $55^{\circ} 46^{\prime}$ с.ш., $66^{\circ} 21^{\prime}$ в.д. \\
\hline 22 & Р. Кизяк & $55^{\circ} 48^{\prime}$ с.ш., $66^{\circ} 46^{\prime}$ в.д. \\
\hline 22 & Р. Кизяк & $55^{\circ} 55^{\prime}$ с.ш., $66^{\circ} 38^{\prime}$ в.д. \\
\hline
\end{tabular}

\section{Материалы и методика исследований}

Отобраны и зафиксированы образцы макроводорослей, собран гербарий гидромакрофитов, насчитывающий 100 листов. При изучении таксономической принадлежности растений использованы микроскопы Альтами СПМ 0880 и Альтами Био-1. Для определения макроскопических водорослей применяли цифровые видеоокуляры DCM и UCMOS 5100 KPA. Латинские названия видов макроскопических водорослей приведены по определителю [10]. Для выявления видовой принадлежности сосудистых гидромакрофитов использовали определители [11]. Латинские названия видов цветковых гидрофитов приведены по работе С.К. Черепанова [12]. Порядок расположения семейств цветковых дан по А.Л. Тахтаджяну [13]. Роды и виды внутри семейств расположены в алфавитном порядке латинских названий растений. Нумерация видов в списке дана сквозная. Градация частоты встречаемости аналогична той, что использовалась в работе [14, с. 16].

Координаты пунктов определяли с помощью навигаторов Garmin GPSMAP 64. Водные объекты, низшие и высшие гидромакрофиты, а также их группировки и сочетания группировок в естественных условиях фотографировались цифровыми фотокамерами Canon.

Образцы макроскопических водорослей определены Т.В. Свириденко - с.н.с. научно-образовательного центра Института естественных и технических наук Сургутского государственного университета (г. Сургут). 
Результаты исследований и их обсуждение

В составе водной гидромакрофитной флоры исследованных водоемов выявлено 47 видов из 30 родов и 21 семейства. Ниже приведен список гидромакрофитов водоемов северо-восточной части Курганской области.

\section{Charophyta - Харовые водоросли}

1. Characeae - Харовые

1. Chara contraria A. Br. - Хара противоположная

2. Chlorophyta - Зеленые водоросли

2. Cladophoraceae - Кладофоровые

2. Cladophora fracta (Müll. ex Vahl) Kütz. Кладофора слабая

3. Cladophora glomerata (L.) Kütz. - Кладофора скученная

4. Cladophora rivularis (L.) Hoek - Кладофора речная

5. Rhizoclonium hieroglyphicum (Ag.) Kütz. Ризоклониум иероглифический

3. Spirogyraceae - Спирогировые

6. Spirogyra decimina (Müll.) Kütz. - Спирогира десятерная

7. Spirogyra neglecta (Hass.) Kütz. - Спирогира забытая

8. Spirogyra setiformis (Roth) Kütz. - Спирогира щетинковидная

4. Ulvaceae - Ульвовые

9. Enteromorpha intestinalis (L.) Link. - Энтероморфа кишечновидная

10. Enteromorpha flexuosa (Wulf) J. Ag. Энтероморфа извилистая

3. Equisetophyta - Хвощевидные

5. Equisetaceae - Хвощевые

11. Equisetum fluviatile L. - Хвощ речной

4. Magnoliophyta - Цветковые

6. Nymphaeaceae - Кувшинковые

12. Nuphar lutea (L.) Smith - Кубышка желтая

7. Ceratophyllaceae - Роголистниковые

13. Ceratophyllum demersum L. - Роголистник погруженный

14. Ceratophyllum submersum L. - Роголистник подводный

8. Polygonaceae - Гречишные

15. Persicaria amphibia (L.) S.F. Gray - Горец земноводный

9. Haloragaceae - Сланоягодниковые

16. Myriophyllum sibiricum Kom. - Уруть сибирская

10. Lentibulariaceae - Пузырчатковые

17. Utricularia vulgaris L. - Пузырчатка обыкновенная

11. Hippuridaceae - Хвостниковые

18. Hippuris vulgaris L. - Хвостник обыкновенный, водяная сосенка

12. Butomaceae - Сусаковые

19. Butomus umbellatus L. - Сусак зонтичный

13. Hydrocharitaceae - Водокрасовые

20. Elodea canadensis Michx. - Элодея канадская

21. Hydrocharis morsus-ranae L. - Водокрас обыкновенный

22. Stratiotes aloides L. - Телорез обыкновенный
14. Alismataceae - Частуховые

23. Alisma gramineum Lej. - Частуха злаковидная

24. Alisma plantago-aquatica L. - Частуха подорожниковая

15. Potamogetonaceae - Рдестовые

25. Potamogeton crispus L. - Рдест курчавый

26. Potamogeton friesii Rupr. - Рдест Фриза

27. Potamogeton lucens L. - Рдест блестящий

28. Potamogeton pectinatus L. - Рдест гребенчатый

29. Potamogeton perfoliatus L. - Рдест пронзеннолистный

30. Potamogeton pusillus L. - Рдест маленький

31. Potamogeton trichoides Cham. et Schlecht. - Рдест волосовидный

16. Ruppiaceae - Руппиевые

32. Ruppia maritima L. - Руппия морская

17. Суреraceae - Осоковые

33. Bolboschoenus maritimus (L.) Palla Клубнекамыш морской

34. Bolboschoenus planiculmis (Fr. Schmidt) Egor. - Клубнекамыш плоскостебельный

35. Carex acuta L. - Осока острая

36. Eleocharis palustris (L.) Roem. et Schult. - Ситняг болотный

37. Scirpus lacustris L. - Камыш озерный

38. Scirpus tabernaemontani C.C. Gmelin Камыш Табернемонтана

18. Роасеае - Мятликовые

39. Agrostis stolonifera L. - Полевица побегообразующая

40. Phragmites australis (Cav.) Trin. ex Steud. - Тростник южный

41. Scolochloa festucacea (Willd.) Link Тростянка овсяницевая

19. Lemnaceae - Рясковые

42. Lemna minor L. - Ряска малая

43. Lemna trisulca L. - Ряска тройчатая

44. Spirodela polyrhiza (L.) Schleid. - Многокоренник обыкновенный

20. Sparganiaceae - Ежеголовниковые

45. Sparganium emersum Rehm. - Ежеголовник всплывший

21. Typhaceae - Рогозовые

46. Typha angustifolia L. - Рогоз узколистный

47. Typha latifolia L. - Рогоз широколистный

Основу флоры формируют представители отдела Magnoliophyta (36 видов, или 77\%). Следовательно, по систематическому составу водная флора водоемов является цветковой. К ведущим классам относятся Liliopsida (62\% видов, 57\% родов) и Magnoliopsida (17\% видов, $23 \%$ родов) - на их долю приходится $79 \%$ видов и $80 \%$ родов (табл. 2 ).

По видовому богатству выделяются семейства Potamogetonaceae (15\% от общего числа видов), Суperaceae $(13 \%)$, Cladophoraceae $(9 \%)$ и семейства Spirogyraceae, Hydrocharitaceae, Poaceae, Lemnaceae, на долю которых приходится по 6\% от общего числа видов. Семейство Турhaceae объединяет 5\% видов. Остальные семейства (62\%) являются одновидовыми. 
Таблица 2 - Таксономическая структура водной гидромакрофитной флоры

\begin{tabular}{|c|c|c|c|c|c|c|}
\hline \multirow{2}{*}{ Отдел } & \multicolumn{2}{|c|}{ Семейства } & \multicolumn{2}{|c|}{ Роды } & \multicolumn{2}{|c|}{ Виды } \\
\cline { 2 - 7 } & абс. & $\begin{array}{c}\text { отн., } \\
\%\end{array}$ & абс. & $\begin{array}{c}\text { отн., } \\
\%\end{array}$ & абс. & $\begin{array}{c}\text { отн., } \\
\%\end{array}$ \\
\hline 1. Charophyta & 1 & 5 & 1 & 3 & 1 & 2 \\
\hline $\begin{array}{c}\text { 2. Chloro- } \\
\text { phyta }\end{array}$ & 3 & 14 & 4 & 13 & 9 & 19 \\
\hline $\begin{array}{c}\text { 3. Equi- } \\
\text { setophyta }\end{array}$ & 1 & 5 & 1 & 3 & 1 & 2 \\
\hline $\begin{array}{c}\text { 4. Magnoli- } \\
\text { ophyta }\end{array}$ & 16 & 76 & 24 & 81 & 36 & 77 \\
\hline Bсего & $\mathbf{2 1}$ & $\mathbf{1 0 0}$ & $\mathbf{3 0}$ & $\mathbf{1 0 0}$ & $\mathbf{4 7}$ & $\mathbf{1 0 0}$ \\
\hline
\end{tabular}

Самым крупным по числу видов является род Роtamogeton (15\% видов). Роды Cladophora, Spirogyra включают по 7\% видов каждый. По 4\% видов объединяют 7 , или $23 \%$ родов. Одновидовыми являются 20 , или $67 \%$ родов.

Распределение видов по водоемам неоднородное и в основном зависит от физико-химических параметров водной среды и их морфометрических характеристик. Максимальное таксономическое разнообразие макроскопических растений отмечено в оз. Песьяное (36\% от общего видового состава), оз. Малое Коровье (34\%), оз. Лихачевское (32\%), оз. Максимково (30\%). Как правило, эти озера отличаются от остальных наименьшими глубинами и наиболее выраженными процессами зарастания акватории подводной растительностью. В составе водной флоры рек Марай и Кизяк описано по 26\% видов, р. Суерь - 23\% видов. Водная флора остальных исследованных водоемов характеризуется очень бедным составом, количество видов меньше 10. Исключительно в составе водной флоре рек были отмечены такие виды, как Nuphar lutea, Utricularia vulgaris, Hippuris vulgaris, Butomus umbellatus и Sparganium emersum.

Анализируя частоту встречаемости гидромакрофитов по территории исследования, мы выделили 6 групп:

1. Виды очень часто встречающиеся - $2 \%$ видов (отмечены более чем в 75\% от числа изученных водоемов): Phragmites australis.
2. Часто встречающиеся - 2\% видов (в 51-75\% водоемах): Potamogeton pectinatus.

3. Умеренно встречающиеся - 17\% видов (в 2650\% водоемах): Cladophora glomerata, C. rivularis, Enteromorpha flexuosa, Alisma gramineum, Scirpus tabernaemontani, Lemna minor, L. trisulca, Potamogeton perfoliatus.

4. Изредка встречающиеся - 12\% видов (в 1125\% водоемах): Cladophora fracta, Rhizoclonium hieroglyphicum, Ceratophyllum demersum, Persicaria amphibia, Elodea canadensis, Bolboschoenus planiculmis, Typha angustifolia, Alisma plantago-aquatica, Potamogeton friesii, Eleocharis palustris, Scirpus lacustris, Scolochloa festucacea.

5. Редко встречающиеся - 17\% видов (до 10\%): Hydrocharis morsus-ranae, Stratiotes aloides, Potamogeton crispus, P. lucens, P. pusillus, Bolboschoenus maritimus, Spirodela polyrhiza, Sparganium emersum.

6. Единично встречающиеся виды - $36 \%$ видов: Chara contraria, Spirogyra decimina, S. neglecta, S. setiformis, Enteromorpha intestinalis, Equisetum fluviatile, Nuphar lutea, Ceratophyllum submersum, Myriophyllum sibiricum, Utricularia vulgaris, Hippuris vulgaris, Butomus umbellatus, Stratiotes aloides, Ruppia maritima, Carex acuta, Agrostis stolonifera, Typha latifolia.

Необходимо сказать, что большинство видов сосудистых гидромакрофитов, отмеченных нами как редко и единично встречающиеся, являются на самом деле распространенными на территории Западно-Сибирской равнины (Северный Казахстан [15]; Тюменская область [14]), кроме вида Ruppia mariti$m a$, который, по мнению С.А. Николаенко и В.А. Глазунова $[16$, с. 1], является критически исчезающим в южных районах Тюменской области. Однако в водоемах Северного Казахстана руппия морская встречается довольно часто, массово развиваясь в равнинных и долинных солоноватых и соляных озерах [15, с. 45].

Вид Ruppia maritima внесен в Красную книгу Курганской области [3, с. 257], относится к I категории (вид, находящийся под угрозой исчезновения). В ходе исследования нами найдено новое местонахождение руппии морской в озере без названия [5, c. 864-865], которое находится в 2,0 км западнее с. Новое Ильинское, на глубине 0,5 м в сообществе с ризоклониумом иероглифическим (рис. 1).
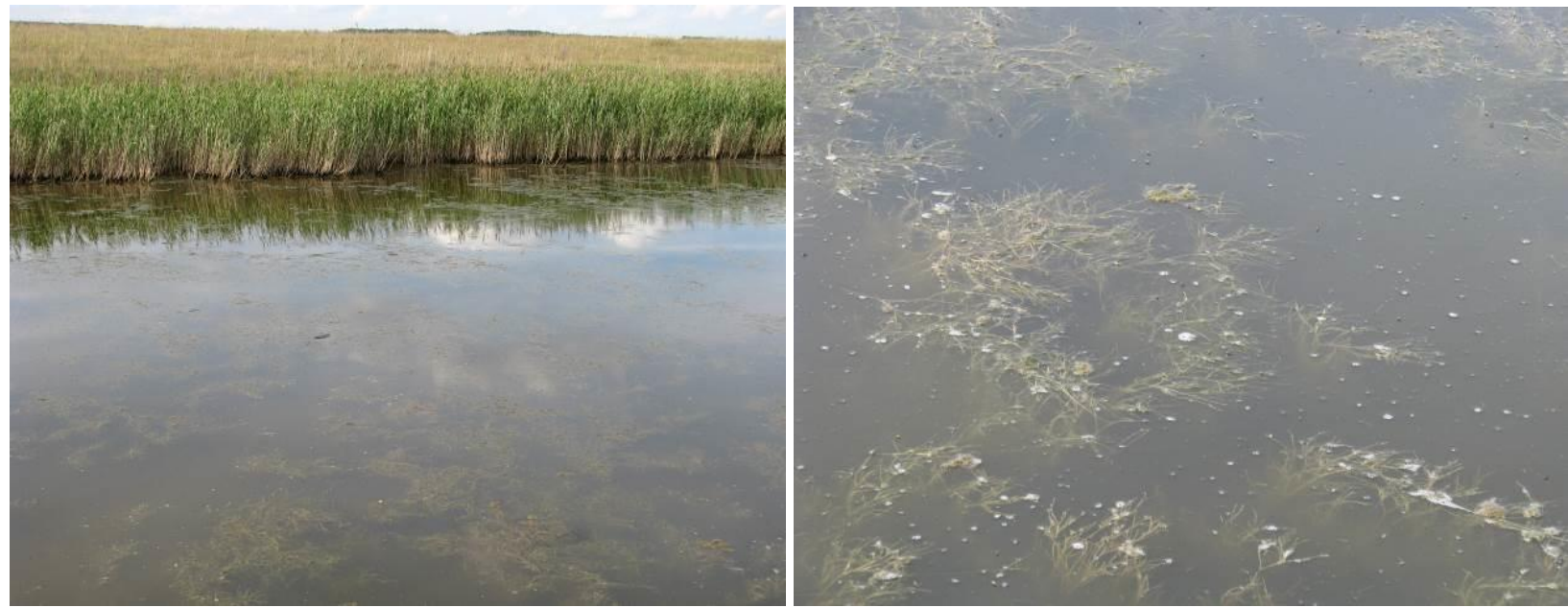

Рисунок 1 - Фитоценоз Ruppia maritima в озере без названия

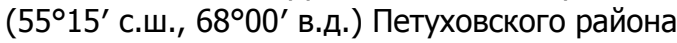


Для оценки риска инвазий чужеродных видов [17, c. 46] научный интерес представляет информация о местонахождении инвазионного вида Elodea canadensis в некоторых водоемах (озера Песьяное, Исаково и Максимково, реки Марай и Суерь) на территории исследования. В водных сообществах большинства водных объектов (кроме р. Суерь) Elodea canadensis проявляет свойства субдоминанта и доминанта, образуя маловидовые сообщества. В водных фитоценозах р. Суерь были отмечены лишь фрагменты побегов этого растения.
Альгофлора водных объектов Курганской области остается в настоящее время малоизученной. В составе альгофлоры исследованных водоемов отмечено 10 видов макроскопических водорослей из 5 родов, 4 семейств, 2 отделов (табл. 1). Это виды, так же как и высшие растения, встречаются в водоемах регионов, граничащих с территорией исследования $[15 ; 18-24]$. Впервые на территории Частоозерского района в озере Песьяное $\left(55^{\circ} 40^{\prime}\right.$ с.ш., $68^{\circ} 08^{\prime}$ в.д.) нами обнаружен вид Chara contraria (рис. 2).

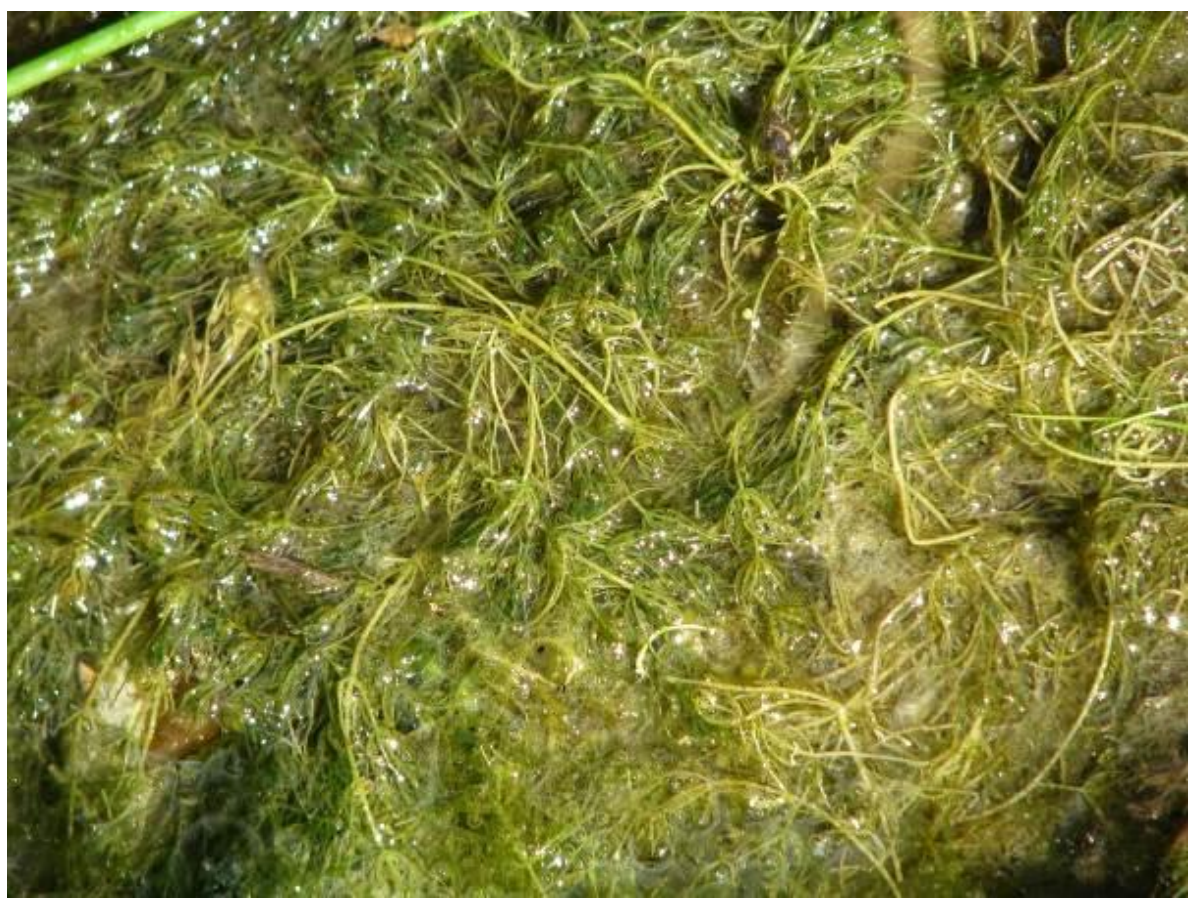

Рисунок 2 - Талломы Chara contraria в озере Песьяное Частоозерского района

Авторы [5, с. 866] считают, что вид Chara contraria, является редким, находится на северной границе своего распространения, поэтому будет целесообразно его включить в очередное издание региональной Красной книги.

\section{Заключение}

На исследованной части Курганской области было выявлено 47 видов из 30 родов, 21 семейства и 3 отделов гидромакрофитов, большинство которых являются распространенными на территории регионов, граничащих с территорией исследования (Cеверный Казахстан, Тюменская область). Однако полученные результаты являются существенным дополнением к уже имеющейся информации о флоре Курганской области. Описаны новые местонахождения редких видов для Западно-Сибирской равнины (Chara contraria и Ruppia maritima). Представлена информация о местонахождении инвазионного вида Elodea canadensis. Считаем, что полученные нами материалы могут служить основой для дальнейшего проведения гидроботанического обследования водоемов Курганской области.

\section{Список литературы:}

1. Науменко Н.И. Флора и растительность Южного Зауралья: монография. Курган: Изд-во Курганского гос. ун-та, 2008. $512 \mathrm{c}$.

2. Красная книга Курганской области. Курган: Зауралье, 2002. 424 c.
3. Красная книга Курганской области. Изд. 2-е. Курган: Изд-во Курганского гос. ун-та, 2012. 448 с.

4. Особо охраняемые природные территории Курганской области: справочник / авт.-сост. Н.И. Науменко, В.В. Тарасов, А.В. Зырянов, А.С. Мочалов, Н.А. Неумывакина, М.И. Шумкова, С.Н. Кузнецова; под ред. И.Н. Некрасова. Курган: Изд-во Курганского гос. ун-та, 2014. $188 \mathrm{c}$.

5. Свириденко Б.Ф., Свириденко Т.В., Ефремов А.Н., Токарь О.Е., Мурашко Ю.А. Новые данные для ведения Красной книги Курганской области // Экология и география растений и растительных сообществ: мат-лы 4-й междунар. науч. конф. 1619 апреля 2018 г., г. Екатеринбург, Российская Федерация. Екатеринбург: Урал. ун-т, 2018. С. 864-868.

6. Тебенькова Е.А. Природные ландшафты Курганской области: теория и методика изучения: учебное пособие. Курган: Изд-во Курганского гос. ун-та, 2016. $114 \mathrm{c}$.

7. Завьялова О.В. География Курганской области: учеб. пособие для средней школы. Курган, 1993. $120 \mathrm{c}$.

8. Науменко Н.И. Флористическое районирование Южного Зауралья // Вестник Санкт-Петербургского ун-та. Сер. 3. Биология. 2004. Вып. 1. С. 69-90.

9. Катанская В.М. Высшая водная растительность континентальных водоемов СССР: методы изучения. Л.: Наука, 1981. 187 с. 
10. Определитель пресноводных водорослей СССР. Л.: Наука, 1951-1983. Т. 1-14.

11. Флора Сибири: В 14 т. Новосибирск: Наука, 1987-2003. Т. 1-14.

12. Черепанов С.К. Сосудистые растения России и сопредельных государств (в пределах бывшего СССР). СПб.: Мир и семья, 1995. 992 с.

13. Тахтаджян А.Л. Система магнолиофитов. Л.: Наука, 1987. 440 c.

14. Токарь О.Е. Флора, растительность и фитоиндикация состояния водных экотопов реки Ишим и пойменных озер в пределах Тюменской области: монография. Ишим: ИГПИ им. П.П. Ершова, 2006. $208 \mathrm{c}$.

15. Свириденко Б.Ф. Флора и растительность водоемов Северного Казахстана. Омск: Изд-во ОмГПУ, 2000. $196 \mathrm{c}$

16. Николаенко С.А., Глазунов В.А. Редкие виды растений водной флоры лесостепной зоны Тюменской области // Вестник экологии лесоведения и ландшафтоведения. 2008. Вып. 9. С. 48-54.

17. Свириденко Б.Ф., Свириденко Т.В., Ефремов А.Н., Токарь О.Е., Евженко К.С. Элодея канадская Elodea canadensis (Hydrocharitaceae) на ЗападноСибирской равнине // Вестник Томского государственного университета. Биология. 2013. № 3 (23). C. $46-55$.

18. Свириденко Т.В., Свириденко Б.Ф. Харовые водоросли (Charophyta) Западно-Сибирской равнины. Омск: Амфора, 2016. 247 с.

19. Свириденко Б.Ф., Свириденко Т.В. Макроскопические водоросли Западно-Сибирской равнины: учебное пособие. Сургут: ИЦ СурГУ, 2010. 92 с.

20. Свириденко Б.Ф., Евженко К.С., Ефремов А.Н., Токарь О.Е., Свириденко Т.В., Окуловская А.Г. Семейство Spirogyraceae (Zygnematales) на ЗападноСибирской равнине // Экологический мониторинг и биоразнообразие: мат-лы 4-й междунар. науч.-практ. конф. / под ред. А.Ю. Левых. Ишим: ИГПИ им. П.П. Ершова, 2012. С. 44-57.

21. Свириденко Б.Ф., Евженко К.С., Ефремов А.Н., Токарь О.Е., Свириденко Т.В., Окуловская А.Г. Зигнемовые водоросли (Zygnematales) в растительных группировках водных объектов Западно-Сибирской равнины // Биогеоценология и ландшафтная экология: итоги и перспективы: материалы международной конф., посв. памяти Ю.А. Львова. Томск, 2012. C. 283-287.

22. Свириденко Б.Ф., Евженко К.С., Ефремов А.Н., Токарь О.Е., Свириденко Т.В., Окуловская А.Г. Широтно-зональное распределение зигнемовых водорослей (Zygnematales) на Западно-Сибирской равнине // Вестник Санкт-Петербургского ун-та. Серия 3. Вып. 4. 2012. С. 38-49.

23. Свириденко Б.Ф., Свириденко Т.В., Токарь О.Е., Евженко К.С., Ефремов А.Н., Окуловская А.Г. Макроскопические водоросли в гидроэкосистемах Западно-Сибирской равнины // Известия Омского регионального отделения Всероссийской общественной организации «Русское географическое общество». 135 лет Омского отделения РГО в 300-летней истории г. Омска. Омск: Амфора, 2012. C. 62-70.

24. Свириденко Т.В., Свириденко Б.Ф., Токарь О.Е., Евженко К.С., Ефремов А.Н. Харовые водоросли (Charophyta) в растительных группировках водных объектов Западно-Сибирской равнины // Природные ресурсы, биоразнообразие и перспективы естественнонаучного образования: мат-лы международной научно-практической конференции, посвященной памяти И.В. Бекишевой - ученого и педагога. Омск: ОмГПУ, 2012. С. 81-87.

Статья публикуется при поддержске гранта РФФИ и Правительства Ханты-Мансийского автономного округа - Югры в рамках научного проекта «р_урал_а» (15-44-00014).

\section{HYDROMACROPHYTES COMPOSITION IN WATER RESERVOIRS OF THE NORTH-EASTERN PART OF THE KURGAN REGION}

(C) 2018

Tokar Olga Egorovna, candidate of biological sciences, associate professor of Biology, Geography and Methods of Teaching Department P.P. Ershov Ishim Pedagogical Institute (branch) of Tyumen State University

(Ishim, Tyumen Region, Russian Federation)

Abstract. Hydromacrophyte flora of 22 water bodies in the Kurgan Region was studied in 2017. The aquatic study was conducted within the 6 administrative districts of the Kurgan Region: Chastoozersky (4), Petrovsky (2) Makushinski (7), Lebyazhyevsky (4), Vargashinsky (2), and Mokrousovsky (3). The area of the research was between $55^{\circ} 09$ minutes of the North latitude and $55^{\circ} 48^{\prime}$ of the North latitude, from West to East - between $65^{\circ} 53^{\prime}$ of the East latitude and $69^{\circ} 19$ minutes of the East latitude. During the research we selected and recorded samples of macroalgae and collected herbarium of higher hydromacrophytes. The paper contains data on species composition and frequency of hydromacrophytes occurrence; new location of Ruppia maritima L. that is considered to be rare in the Kurgan Region was found. It's the first time the specific structure of macroscopic algae has been given for the territory of research. It is noted that the species of Chara contraria A. Br., is a rare one, and here it is located on the Northern border of its distribution, therefore it needs protection. Most of the identified species of hydromacrophytes are common in the West Siberian plain (Northern Kazakhstan, Tyumen Region). The paper also contains information about the location of invasive species Elodea canadensis Michx. The obtained materials can serve as a basis for further hydrobotanical study of water reservoirs in the Kurgan Region.

Keywords: hydromacrophytes; species composition; frequency of occurrence; water reservoirs; Kurgan Region; Chastoozersky District; Petrovsky District; Makushinsky District; Lebyazhievsky District; Vargashinskiy District; West Siberian plain; macroalgae; rare species; Ruppia maritima; Chara contraria; Elodea canadensis. 